\title{
Sosyal Medyanın Toplumsal Dönüştürücülüğü: Sosyal Medya Kullanan Ergenlerin Aile İçi İletişim Süreçlerine Katılım Düzeyleri Üzerine Nicel Bir Araştırma
}

\author{
DOI: $10.26466 /$ opus.777748
}

*

\author{
Serpil Kir Elitaș * \\ * Dr. Öğretim Üyesi, Hatay Mustafa Kemal Üniversitesi, İletişim Fakültesi, Hatay/Türkiye \\ E-Posta: serpilkiir@gmail.com \\ ORCID: 0000-0002-6653-6102 \\ Öz
}

Internetin gelişimi ile birlikte hızla artmaya devam eden sosyal medya kullanımı günlük hayatımızı farklı şekillerde etkilemeye başlamıştır. Olumlu ve olumsuz etkilerinin sürekli tartışıldığı sosyal medya, günümüzde insanların günlük rutinleri arasında bulunan ve kullanan insan sayısının devaml bir artış gösterdiği bir araçlar bütünü durumuna gelmiştir. Bu artış ile birlikte bireylerde de farkl dönüşümler yaşanmış ve kişilerarası iletişim özelinde özellikle aile içi iletişimin dijital ortamlara taşınmasına neden olmuştur. Bu çalışmada da bireyin teknoloji ile olan ilişkisi temelinden yola çıkılarak, 2018-2019 Eğitim Öğretim yıl bahar döneminde Hatay ilinde eğitimlerine dört ortaöğretim kurumunda değiş̧ik sinıf seviyelerinde devam etmekte olan 356 öğrencinin sosyal medya kullanım düzeylerine göre aile içi iletişimin farklılaşma durumu araştırılmıştır. Araştırmada sosyal medya ve aile içi iletişim ölçeği kullanılmış ve veriler yüz yüze anket yöntemi kullanilarak elde edilmiştir. Araştırma sonucunda ergen bireylerin aile içi iletişim süreçlerine katılım düzeylerindeki azalma sebepleri arasında sosyal medyanın \% 22'lik bir etkisi bulunduğu, özellikle gün içinde ergen bireylerin sosyal medyayı kullanım süreleri arttıkça fiziksel katılım să̆lanan ilişki pratiklerinde azalma olduğu sonuçlarına ulaşılmıştır.

Anahtar Kelimeler: Aile içi iletişim, Sosyal Medya, Toplumsal Dönüşüm, İnternet 


\title{
Social Transformation of Social Media: A Quantitative Research on the Participation Levels of Adolescents Using Social Media in Family Communication Processes
}

*

\begin{abstract}
The use of social media, which continues to increase rapidly with the development of the internet, has started to affect our daily life in different ways. Social media, where its positive and negative effects are constantly discussed, has become a set of tools that are among the daily routines of people and the number of people who use it is constantly increasing. With this increase, different transformations have been experienced in individuals, and in particular, interpersonal communication has led to the transfer of intra-family communication to digital environments. In this study, based on the relationship between the individual and technology, the differentiation of domestic communication among the 356 students who continue their education in different grade levels in four secondary education institutions in Hatay province in the spring term of 2018-2019 academic year was investigated. In the research, social media and family communication scale was used and data were obtained by using face-to-face survey method. As a result of the research, it has been concluded that social media has a $22 \%$ effect among the reasons for the decrease in the level of participation of adolescents in the family communication processes, and that there is a decrease in the relationship practices with which physical participation is increased as the usage time of adolescents increases.
\end{abstract}

Keywords: Family communication, Social Media, Social Transformation, Internet 


\section{Giriş}

Modern insanın yaşamında geniş bir yer bulan internetin günümüzde hizmetlerin yaygınlaşması ve çeşitlenmesi ile birlikte, yaşamın vazgeçilmez temellerinden biri haline dönüşmüştür. Birçok iş ve işlemin internet üzerinden daha kısa sürede çözülmesi, hizmetlerin çeşitliliği, iletişim araçları ve alışveriş ile internet, bireylerin hayatının merkezinde yer bulmuştur. Teknoloji ve bireyin bu kadar yakın ilişki içerisinde olması yeni bir etkileşim ve iletişim ortamının oluşmasına neden olmuştur. İnternet, iletişimi biçimlendirerek etkileşimli sanal bir dünyanın oluşumunu sağlamıştır (Kırık, 2014, s.339). Bireyler bilgi, düşünce ve deneyimlerini birbirleriyle paylaşmakta ve bu paylaşımlar bireylerin birbirleri ile olan ilişkilerini ve davranışlarını değiştirmektedir. Özellikle günümüz gençliği bu yeni ve güçlü kaynaktan oldukça büyük ölçüde etkilenmektedir.

Bu dönemde gelişen sosyal medya, yeni ve eski arkadaşlarınızla iletişim kurmanın, ağları takip etmenin, markaları ve şirketleri takip etmenin bir tık uzağında olduğu kolay bir yolunu sunmaktadır. Her kullanıcının hayatının mini bir biyografisini sunan sosyal medya, ayn zamanda 'fenomenlik' kavramı ile birlikte ergenlerin günlük yaşamlarının ayrılmaz bir parçası ve çoğunluğun kullandığı en popüler iletişim biçimlerinden biri haline gelmiştir. Aslında sosyal medya günlük yaşam ve kişilerarası iletişimi etkileyen, günlük konuşmaları biçimlendiren, iletişimi düzenleyen ve sürdürülmesini sağlayan bir araç haline dönüşmüştür (Elitaş, 2015, s.245).

Bununla birlikte, günden güne artan sosyal medya kullanımı bireyler ve özellikle aileler arasında iletişim kopukluklarına neden olmaktadır. "Sosyal medyada geçirilen zaman arttıkça aile ilişkilerinde o oranda azalma görülmektedir. Sosyal medyanın yoğun olarak kullanılması sadece aile ilişkilerini değil ailede yaşanacak başka sorunlara da sebep olmaktadır" (Güleç, 2018, s.105). Zamanlarının büyük bir çoğunluğunu sosyal paylaşım ağlarında geçiren ergenler (Haciefendioğlu, 2010, s.57), odalarında yalnız ve sosyal hayattan izole bireylere dönüşmektedir. Sosyal medya ile iletişim boşluğunu tamamlayan ya da iletişim argümanlarına yeni pratikler eklemleyen bireyler, sosyal faaliyetlerde bulunmak yerine, internette vakit geçirmeyi tercih etmekte ve bu durum aile bireylerinin boş zamanlarını ayrı geçirilmesi durumunu ortaya çıkarmaktadir (Aslan ve Cansever, 2012, s.31). Kendilerini sosyal hayattan izole eden gençler, gerçek hayatta yaşanılan olaylardan uzaklaşarak sanal dünyanın bir 
parçası haline gelmekte ve fiziksel yaşama dönük sosyalleşmekten yoksun kalabilmektedirler.

Demir (2016, s.32), bireylerin ailesi ve yakın çevresi ile olan etkileşimlerinde sosyal medyanın olumsuz etkisi olduğunu savunmaktadır. Gençlerin fazla internet kullanımlarının nedeni olarak aile ve arkadaş ilişkilerinin zayıf olmasının ilişkilendirilebileceğini ifade etmektedir. Ayrıca sosyal medyayı yoğun kullanan öğrencilerin dışarıya çıkmadıkları zamanlar olduğunu, aile içerisindeki konuları sıkıcı bulduklarını, özel sorun ve problemlerini arkadaşlarıyla paylaştıkları sonuçlarına varmıştır. Çalışmasında, bir haftada beş saatten fazla internet kullanan gençlerin ailelerine ve arkadaşlarına ayırdıkları zamanı azalttıkları; bunların \%10'unun ise internet yüzünden ev dışı aktivitelere az katıldıkları görülmüştür. Aynı düşünceleri paylaşan Villegas (2013, s.13) sosyal medyanın kişinin aile ile olan iletişimini olumsuz yönde etkileyerek, yüz yüze etkileşimleri ve toplumsal katılımı engelleme potansiyeline sahip olduğunu savunmaktadır.

Sosyalleşme sorunlarının yanı sıra sosyal medyanın ergenlerin akran ilişkileri üzerinde olumsuz etkileri de bulunmaktadır. Güleç (2018, s. 118), sosyal medyanın, aile içi iletişimini, akran iletişimini ve ebeveyn- çocuk iletişimini olumsuz yönde etkileyerek zarar verdiğini ifade etmektedir.

Ergenlerin sosyal medyayı aktif kullanımı ve sanal uzamlarda yeni uylaşım süreçlerine dâhil olması ile birlikte fiziksel katılımın mekânsal ve örgütsel kurucusu toplumsal organizasyonlar silikleşmeye başlamakta ve ortaya gerçek ve sanaldan oluşan hibrit bir yaşam döngüsü çıkmaktadır. Dijital kimlikleri ile sosyal medyada dijital toplum vatandaşı olan ergenler sanal uzamların bahşettiği yersiz ve yurtsuz dolaşım dijital toplumsal örgütlenmelerde benliğini ve bireyliğini paylaşımlarına alınan yorumlarla ve beğenilerle (like) ortaya koyma çabası içerisindedir. Sosyal medya ile kendini dijital kimlikliği ile ortaya koyan ergenler, oluşturmuş olduğu çevre ve kurmuş olduğu ilişki pratikleri ile fiziksel yaşam alanlarının kutsayıcısı ve kısıtlayıcısı normların denetiminden uzaklaşmaktadır.

Anonimlik ve özgürlük kodlarını atfettiği sosyal medya, ergenler için sürekli takipçi sayılarının artırılması gereken ve artan takipçi sayıları ile kazanılan özgüvenin önemli bir yoludur. Bu durum enformasyon çağında ergenlere küresel bir mekânda dijital ama küresel bir vatandaşlık kapsını aralarken, aynı zamanda ergenleri siber ortamdaki bağımlılık başta olmak üzere fiziksel ve manevi bir takım tehlikelere de açık hale getirmektedir. 
Sosyal medya, teknolojinin iletişime entegre olması sonucu mobil teknolojilerin daha da yaygınlaşması ile birlikte aile içerisindeki dinamiklerin değişimine de yol açmaktadır. Aileler açısından güvenlik ve çocuklarını gözetim konularında; gençler açısından da özgürlüklerinin değişimi konusunda tartışmalara neden olmaktadır. Bu değişim, kaynaklara erişim ve derslere yardım konularında olumlu olarak görülebilirken, derslerdeki aksamalar, hile ve zorbalık vakaları olumsuz etkiler arasından bazılarıdır. Güleç (2018, s. 118), özgüvensiz öğrencilerin sosyal medyada sosyal paylaşım sitelerinde tanışık olduğu olmadığı herkesi arkadaşı olarak ekleyerek psikolojik olarak tatmin olmadıkları görüşüne yer vermiştir. Bu durumun olumsuz sonuçları olarak sosyal medyanın çocuklar için açık bir tuzak durumuna dönüşebileceğini ifade etmiştir. Normalde çoğu ebeveyn çocuğunun kimlerle arkadaşlık ettiği hakkında genel anlamda bilgi sahibi olurken, sosyal medya nedeniyle ebeveynler çocuklarının kimlerle arkadaşlık kurduğunu bilememekte, konuştuğu konulardan ya da içeriklerden haberdar olamamaktadır. Bu durumlar sosyal medya aracılığıyla çocukların art niyetli kişiler tarafından daha kolay kandırılabilmelerine yol açmaktadır.

$\mathrm{Bu}$ açıdan ebeveynlerin çocuğa karşı görev ve sorumluluklarının bulunduğunu belirten Karan (2006, s. 36-38), ebeveynlerin, çocukları internetin zararlı etkilerinden koruyabilmesi adına dikkat edilmesi gereken noktaları şu şekilde ifade etmektedir:

- Ebeveynler, çocuklara özgüven aşılamalı ve olumsuzluk teşkil edecek davranışların önüne geçilebilmesi adına çocuklarla paylaşımda bulunmalıdır.

- Çocuklarla sürekli diyalog kurulmalı ve internet ortamında neler yaptığı öğrenilmelidir.

- Çocuğa kişisel bilgilerin önemi anlatılmalı ve bu bilgilerin kimseyle paylaşılmaması gerektiği izah edilmelidir.

Tüm bu bilgiler ışığında çalışma sosyal medyanın toplumsal dönüştürücü etkisini merkeze alarak ergen bireylerin aile içi iletişim süreçlerindeki katılım düzeylerini belirlemeyi amaçlamaktadır. Alan yazında sosyal medyanın etkisi üzerine birçok yabancı ve yerli araştırma mevcuttur. Ancak ergenlerin aile içi iletişim süreçlerinde sosyal medyanı kullanımın etkisini ortaya koyabilecek nicel çalışmaların oldukça yetersiz olması bu çalışmanın önemini daha da artırmaktadır. 


\section{Yöntem}

İçinde bulunduğumuz enformasyon çağında teknoloji gerek bireysel gerek organizasyonel tüm pratiklerin düzenlenmesinde ve sürdürülmesinde geleneksele bir alternatif olarak tüm yaşamsal fonksiyonların merkezinde konumlanmıştır. Teknolojinin kutsandığı bu çağda özellikle yeni iletişim teknolojileri bireylerin teknoloji ile olan yakınlaşmasında ve teknolojiyi özümsemesinde önemli bir aktör olarak enformasyon çağının önemli bir argümanı olmaktadır.

Yeni iletişim teknolojilerinin en önemli çıktısı kuşkusuz sosyal medyadır. İletişimsel pratiklerin uygulayıcılığının yanı sıra eş zamanlı etkileşimi destekleyen bir uzam olan sosyal medya, aynı zamanda enformasyon çağının en önemli günlük rutin ihtiyaçlarının dijital mekânıdır. Bugün sosyal medya kullanıcı sayısı, internetin altyapısal olarak birçok noktaya ulaşması ve taşınabilir cihazların internet kullanımına imkân verecek şekilde güncellenmesi sayesinde her geçen gün artmaktadır. Ağustos 2019 yılı itibariyle Türkiye'de aktif sosyal medya kullanıcısı sayısı 52 milyon 'dur. Bu sayı ülke nüfusun \%63 üne tekabül etmektedir (We are social ve Hootsuit, 2019). Türkiye'de her yıl yaklaşık 2 milyon yeni kullanıcı sosyal medya kullanmaya başlamaktadır. Özellikle 2000 ve sonrası doğan Z kuşağının, sosyal medyanın sürekli artan kullanıcı ortalamalarında önemli bir kitle olduğu birçok bilimsel veri ile kanıtlanmıştır. Postmodern yaşam kodlarının giderek daha da fazla yaygınlaştığı bir süreçte yetişkin olacak bu kitle, özellikle aktif ilişki pratiklerini dizayn etmeye başladığ 1 dönemde sosyal medya ile tanışmaktadır. Bu inşa sürecinde hem fiziksel katılım sağladığı çevre hem de dijital kimlikleri ile katılım sağladığı sanal uzamlar arasında kalan birey, özellikle iletişimsel eylemlerinde eşgüdümsel pratikler geliştirmek zorunda kalmaktadır.

\section{Problem Sorusu}

Postmodernliğin şafağında dijital yaşam örüntülerinin fiziksel yaşamları kuşatması ve onu dönüştürmesi neticesinde sosyal medya mecraları önemli sosyalleşme mekânları olmaya başlamış ve bu mekânlardaki ilişki pratikleri fiziksel katılım sağlanan gerçeğin aurasını silikleştirmeye başlamıştır.

Bu düşünceden yola çıkılarak araştırmada, $Z$ kuşağı olarak değerlendirilen 'ergenlerin fiziksel olarak katılım sağladığı aile içi iletişim süreçlerine katılım düzeyleri ile sosyal medya kullanımı arasındaki ilişkinin olup olmadığı' 
sorusu çalışmanın temel problemini oluşturmaktadır. Ayrıca çalışmada şu sorulara da cevap aranmaktadır:

- Ergenlerin cinsiyetleri ile sosyal medya kullanım geçmişleri arasında anlamlı farklılık var mıdır?

- Ergenlerin sosyal medyayı gün içinde kullanım süreleri ile aile içi paylaşımları arasında anlamlı farklılık var mıdır?

- Ergenlerin cinsiyetleri ile aile içi paylaşımları arasında anlamlı bir farklılik var midır?

\section{Ana Kitle ve Örneklemin belirlenmesi}

Araştırmanın evrenini Hatay ilinde yaşayan ve ilde faaliyet gösteren dört Fen Lisesi'nde 9., 10., 11., 12. sınıflarda öğrenim gören 2080 öğrenci oluşturmaktadır. Amaçlı basit rastgele örneklem yöntemi tekniğinin kullanıldığı çalışmada örneklem birimi ise evreni \% 5'lik hata payı ile temsil edecek 356 öğrenciden oluşmaktadır. Evrende bulunan her bireyin örnekleme dâhil edilme noktasında eşit şanslara sahip olduğu amaçlı rasgele örnekleme yönteminin zengin verilere ulaşabilmek ve çalışmanın güvenilirliğini artırabilmek için araştırmanın amaçları doğrultusunda durum örneklerinin amaçlı bir şekilde tasnif edilmesidir (Baltacı, 2018, s. 258). Çalışmanın evrenini temsil edecek örneklem biriminde veri setine dâhil edilen kullanıcıların 204'ü erkek, 152'si ise kızlardan oluşmaktadır.

\section{Kapsam ve Sintrlliklar}

Bu araştırma sosyal medya kullanan ergenlerin aile içi iletişim süreçlerine katılım düzeylerini kapsamaktadır. Bu bağlamda çalışmada bazı sınırlılıklara gidilmiştir. Mekânsal olarak Hatay iliyle sınırlandırılan çalışmanın bir diğer sınırlılı̆̆ 1 ise örneklem birimi olarak seçilen ergenlerin yaşları noktasındadır. 14 ve 18 yaşlarından oluşan örneklem birimlerinde sosyal medya kullanmayanlar çalışmaya dâhil edilmemiştir.

\section{Veri toplama aracı}

Sosyal medya kullanım bilgilerini ve bu durumun aile içi iletişime etkisini belirlemek amacıyla oluşturulan anket formu, Ümit Demir'in 2016 yılında geliştirdiği ‘Sosyal Medya Kullanımı ve Aile İçi İletişim Ölçeği'nden faydalanılarak oluşturulmuştur. Toplam 18 maddeden oluşan 4 faktörlü Sosyal Medya 
Kullanımı ve Aile İçi İletişim Ölçeği beşli likert tipi ölçektir. Bu çalışmada, 'Sosyal Medya Kullanımı ve Aile İçi İletişim Ölçeği'nin 8 maddesi çalışmanın hipotezlerine uygun bulunarak kullanılmıştır. Paylaşım, sosyal medya bağımlılığı, sosyal izolasyon ve ortak kaliteli zaman geçirme faktörlerinden oluşan ölçekte faktörler toplam varyansın \%52'sini açıklamaktadır. Cronbach's Alpha güvenilirlik katsayısının .84 olarak bulunduğu ölçekte örneklem büyüklügünü test etmek için ise kullanılan $\mathrm{KMO}$ değerlerinin anlamlı ve yeterli seviyede olduğu tespit edilmiştir (Demir,2016).

Çalışma kapsamında anket formu 2018-2019 Eğitim Öğretim yılı bahar döneminde Hatay ilinde eğitimlerine dört ortaöğretim kurumunda devam eden öğrencilere uygulanmıştır. Veri toplama sürecinde hem ölçeğin maddelerini hem de demografik bilgileri kapsayacak şekilde standart bir anket formu hazırlanarak örneklem birimlerine bu form aynı anda dağıtılmıştır. Ters puanlamanın yapılmadığı maddeler "Kesinlikle Katılıyorum (5), Katıllyorum (4), Kararsızım (3), Katılmıyorum (2), Kesinlikle Katılmıyorum (1)" şeklinde puanlanmıştır.

Anket formu 32 maddeden oluşmaktadır. Bu maddelerin ilk 18 tanesi sosyal medya kullanımı ve aile içi iletişim ölçeğini kapsarken diğer maddeler demografik bilgi ve sosyal medyayı kullanma süre ve amaçlarını belirleyebilecek maddelerden oluşmaktadır.

\section{Verilerin Analizi}

Saha çalışmasının Şubat 2019 tarihinde gerçekleştirildiği çalışmada yüz yüze anket tekniği kullanılmıştır. Elde edilen verilere ait istatistiksel çözümlemeler SPSS 20 paket programı kullanılarak gerçekleştirilmiştir.

Ergenlerin verdikleri cevapların güvenirliğini belirleyebilmek amacıyla Cronbach Alfa güvenirlik katsayısına bakılmıştır. Buna göre ölçeğin Hatay ili lise öğrencisi olan ergen bireyler için Cronbach Alfa katsayısı .871 olarak bulunmuştur.

Gönüllüllük esasına göre çalışmaya katılan ergenlerin demografik özellikleri frekans analizi ile sosyal medya kullanımı ve aile içi iletişim ölçeği puanları ise tanımlayıc istatistikler ile belirlenmiştir. Sosyal medya kullanımı ve aile içi iletişim ölçeği için elde edilen verilerin normal dağılımını test etmek için Skewness ve Kurtosis değerlerine bakılmış ve Tabachnik ve Fidell'in 
(2013) $-1,0$ ile $+1,0$ değerlerin normal için yeterli olacağ görüşü referans al1narak, verilerin normal dağılıma sahip olduğu tespit edilmiş, dolayısıyla verilerin analizi için parametrik testler kullanılmıştır. Verilerin analizinde frekans analizi ve $T$ Testi analizinden yararlanılmıştır.

\section{Bulgular}

Araştırma 204'ü erkek ve 152'si kız olmak üzere 356 katılımcı ile gerçekleştirilmiştir. Bu yönüyle çalışmanın hem cinsiyetlerin temsili hem de örneklemin yeterliliği açısından uygun olduğu sonucuna varılmıştır. Katılımcıların yaşları 14 ila 18 yaş arasında değişen ergen bireylerdir. Katılımcılara 32 maddelik anket formunu gönüllük esasına göre doldurmaları istenmiştir.

Tablo 1. Ergen bireylerin sosyal medya kullanım geçmişi

\begin{tabular}{|c|c|c|c|c|}
\hline Değişken & & Frekans $(n)$ & Yüzde (\%) & Geçerli Yüzde (\%) \\
\hline \multirow{6}{*}{ Sosyal Medya Kullanım Geçmişi } & 1 yıldan az & 12 & 104 & 104 \\
\hline & $1-2$ yil & 47 & 20,8 & 20,8 \\
\hline & $3-4$ yil & 121 & 47,8 & 47,8 \\
\hline & $5-6$ yil & 116 & 12,6 & 12,6 \\
\hline & 7 yıl üzeri & 60 & 8,4 & 8,4 \\
\hline & Toplam & 356 & 100,0 & 100,0 \\
\hline
\end{tabular}

Çalışma kapsamında 14-18 yaş arasındaki ergen bireylerin sosyal medya ile olan geçmişi incelendiğinde yüzde $16^{\prime} l 1 k$ bir kesimin 7 yıldan fazla bir süredir sosyal medya kullandığı ortaya çıkmaktadır. Bu örüntülere bakıldığında ergen bireylerin sosyal medya konusunda yüksek düzeyde deneyim sahibi olduğu görülmektedir.

Tablo 2. Ergen bireylerin cinsiyetleri ile sosyal medya kullanım geçmişleri arasındaki farklhlı̆a ilişkin bulgular

\begin{tabular}{llllllll}
\hline Değişken & Cinsiyet & $\mathbf{N}$ & $\overline{\mathbf{X}}$ & SS & SD & $\mathbf{t}$ & $\mathbf{p}$ \\
\hline Sosyal Medya & Erkek & 204 & 3,27 & 1,105 & \multirow{2}{*}{354} & \multirow{2}{*}{3,001} & \multirow{2}{*}{, $003^{*}$} \\
Kullanım Süresi & Kadın & 152 & 3,60 &, 943 & & \\
\hline
\end{tabular}

Ayrıca çalışmaya katılan ergen bireylerin cinsiyete göre sosyal medya kulanım puanları incelendiğinde, t-test sonuçlarına göre anlamlı bir fark tespit edilmiştir $(p<0,05)$. Bu sonuca göre cinsiyeti kadın ergen bireylerin sosyal medya kullanım süreleri açısından erkek ergenlere kıyasla daha uzun süredir sosyal medya kullandıkları söylenebilmektedir. 
Tablo 3. Ergen bireylerin günlük sosyal medya kullanım süreleri

\begin{tabular}{lllll}
\hline Değişken & & Frekans $(\boldsymbol{n})$ & Yüzde (\%) & Geçerli Yüzde (\%) \\
\hline \multirow{4}{*}{ Sosyal Medya Kullanım Süresi } & 1 saatten az & 37 & 104 & 104 \\
\cline { 2 - 5 } & 1-2 saat & 74 & 20,8 & 20,8 \\
\cline { 2 - 5 } & 3-4 saat & 170 & 47,8 & 47,8 \\
\cline { 2 - 5 } & 5-6 saat & 45 & 12,6 & 12,6 \\
\cline { 2 - 5 } & 7 saat üzeri & 30 & 8,4 & 8,4 \\
\cline { 2 - 5 } & Toplam & 356 & 100,0 & 100,0 \\
\hline
\end{tabular}

Çalışmaya katılım sağlayan ergen bireylerin sosyal medyada günün kaç saatini geçirdiği Tablo 3'de görülmektedir. Buna göre Hatay ilinde bulunan 2080 fen lisesi öğrencisinden örneklem birimine dâhil edilen 356 ergen bireyin neredeyse yarısı sosyal medyada 3-4 saatini harcamaktadır. Bağımlılık eşiği olarak nitelendirilebilecek 5 saat üzeri sosyal medya kullanımı ise yüzde 20 civarındadır.

Tablo 4. Sosyal medya kullanan ergenlerin aile içi iletişime katılım süreçleri

\begin{tabular}{|c|c|c|c|c|}
\hline Değişken & & Frekans & Yüzde (\%) & Geçerli Yüzde (\%) \\
\hline \multirow{5}{*}{$\begin{array}{l}\text { Ailemle otururken konuşacak } \\
\text { konu bulamıyorum. }\end{array}$} & Kesinlikle katiliyorum & 14 & 3,9 & 3,9 \\
\hline & Katiliyorum & 47 & 13,2 & 13,2 \\
\hline & Kararsızım & 65 & 18,3 & 18,3 \\
\hline & Katılmiyorum & 128 & 36,0 & 36,0 \\
\hline & Kesinlikle katılmıyorum & 102 & 28,7 & 28,7 \\
\hline \multirow{5}{*}{$\begin{array}{l}\text { Aile içerisinde konuşulan } \\
\text { konular beni çok sıkıyor. }\end{array}$} & Kesinlikle katilıyorum & 22 & 6,2 & 6,2 \\
\hline & Katiliyorum & 55 & 15,4 & 15,4 \\
\hline & Kararsızım & 47 & 13,2 & 13,2 \\
\hline & Katılmıyorum & 142 & 39,9 & 39,9 \\
\hline & Kesinlikle katılmıyorum & 90 & 25,3 & 25,3 \\
\hline \multirow{5}{*}{$\begin{array}{l}\text { Ailemle aynı ortamda hiç ko- } \\
\text { nuşmadığımız zamanlar oluyor. }\end{array}$} & Kesinlikle katilıyorum & 23 & 6,5 & 6,5 \\
\hline & Katiliyorum & 126 & 35,4 & 35,4 \\
\hline & Kararsızım & 37 & 10,4 & 10,4 \\
\hline & Katılmıyorum & 121 & 34,0 & 34,0 \\
\hline & Kesinlikle katılmıyorum & 49 & 13,8 & 13,8 \\
\hline \multirow{5}{*}{$\begin{array}{l}\text { İnternette geçirdiğim süre ai- } \\
\text { lemle tartışmama sebep oluyor. }\end{array}$} & Kesinlikle katilıyorum & 56 & 15,7 & 15,7 \\
\hline & Katiliyorum & 54 & 15,2 & 15,2 \\
\hline & Kararsızım & 65 & 18,3 & 18,3 \\
\hline & Katılmiyorum & 126 & 35,4 & 35,4 \\
\hline & Kesinlikle katılmıyorum & 55 & 15,4 & 15,4 \\
\hline \multirow{5}{*}{$\begin{array}{l}\text { Özel sorun ve problemleri } \\
\text { ailem yerine sosyal medyada } \\
\text { arkadaşlarımla paylaşmayı } \\
\text { tercih ederim. }\end{array}$} & Kesinlikle katıliyorum & 26 & 7,3 & 7,3 \\
\hline & Katılıyorum & 57 & 16,0 & 16,0 \\
\hline & Kararsızım & 28 & 7,9 & 7,9 \\
\hline & Katilmiyorum & 104 & 29,2 & 29,2 \\
\hline & Kesinlikle katılmiyorum & 141 & 39,6 & 39,6 \\
\hline \multirow{5}{*}{$\begin{array}{l}\text { Ailemle zaman geçirirken bile } \\
\text { sosyal medyada olanları merak } \\
\text { ediyorum. }\end{array}$} & Kesinlikle katıliyorum & 25 & 7,0 & 7,0 \\
\hline & Katiliyorum & 63 & 17,7 & 17,7 \\
\hline & Kararsızım & 51 & 14,3 & 14,3 \\
\hline & Katılmıyorum & 126 & 35,4 & 35,4 \\
\hline & Kesinlikle katilmıyorum & 91 & 25,6 & 25,6 \\
\hline
\end{tabular}




\begin{tabular}{|c|c|c|c|c|}
\hline \multirow{5}{*}{$\begin{array}{l}\text { İnternette zamanın nasıl } \\
\text { geçtiğini anlamıyorum. }\end{array}$} & Kesinlikle katılıyorum & 104 & 29,2 & 29,2 \\
\hline & Katıliyorum & 138 & 38,8 & 38,8 \\
\hline & Kararsızım & 54 & 15,2 & 15,2 \\
\hline & Katılmiyorum & 37 & 10,4 & 10,4 \\
\hline & Kesinlikle katılmıyorum & 23 & 6,5 & 6,5 \\
\hline \multirow{5}{*}{$\begin{array}{l}\text { Sosyal medya eğlenceli zaman } \\
\text { geçirmemi sağlıyor. }\end{array}$} & Kesinlikle katıliyorum & 107 & 30,1 & 30,1 \\
\hline & Katıliyorum & 137 & 38,5 & 38,5 \\
\hline & Kararsızım & 58 & 16,3 & 16,3 \\
\hline & Katılmiyorum & 35 & 9,8 & 9,8 \\
\hline & Kesinlikle katılmıyorum & 19 & 5,3 & 5,3 \\
\hline
\end{tabular}

Sosyal medyayı her gün belirli saatlerde kullanan 356 lise çağındaki ergen bireylerin yaklaşı \% 70'inin bu uzamda eğlenceli zaman geçirdiği ortaya çımaktadır. Sosyal medya platformların kullanarak dijital mutluluğu deneyimleyen katılımcların hepsi (\%70) internette zamanın nasıl geçtiğini anlamadığ1 görülmektedir. Çalışma ergen bireylerin aileleri ile zaman geçirmeyi sosyal medyaya tercih ettiğini göstermektedir. Ancak ailesi ile birlikte vakit geçirirken iletişim süreçlerine ergen bireylerin aktif bir katılım sağlamadığı anlaşılmaktadır. Ayrıca iletişim süreçleri noktasında aile içinde pasif, sosyal medyada aktif bir duruş takınan ergen bireylerin özel sorun ve problemlerinin iletişim süreçlerine katılmadığı, ailesi ile paylaştı̆̆ı ve bu konuda sosyal medyaya güvenin tam olarak sağlanamadığı ortaya çıkmaktadır.

Tablo 5. Ergenlerin sosyal medyayı gün içinde kullanım süreleri ile aile içi iletişimlerine ilişkin varyans analizine yönelik bulgular

\begin{tabular}{|c|c|c|c|c|c|c|c|c|}
\hline Değişken & & & $\mathbf{N}$ & $\bar{X}$ & SS & $\mathbf{F}$ & $\mathrm{df}$ & $\mathrm{p}$ \\
\hline \multirow{5}{*}{$\begin{array}{l}\text { Sosyal Medya } \\
\text { Kullanum Süresi }\end{array}$} & \multirow{5}{*}{ Günlük } & 1 saatten az & 37 & 1,72 & 0,662 & \multirow{5}{*}{28,842} & \multirow{5}{*}{4} & \multirow{5}{*}{, $000^{*}$} \\
\hline & & 1-2 saat & 74 & 2,63 & 0,993 & & & \\
\hline & & 3-4 saat & 107 & 2,63 & 1,030 & & & \\
\hline & & 5-6 saat & 45 & 2,82 & 0,873 & & & \\
\hline & & 7 saat üzeri & 30 & 4,1 & 0,203 & & & \\
\hline
\end{tabular}

Yapılan varyans analizinde $\mathrm{p}<0.05$ düzeyinde anlamlı bulunmuştur. $\mathrm{Bu}$ bağlamda ergen bireylerin gün içinde sosyal medyayı kullanım süreleri ile aile içi paylaşımları arasında anlamlı bir farklılık bulunmamaktadır.

Tablo 6. Cinsiyete göre adayların eğitim durumuna ilişkin dağılım.

\begin{tabular}{llll}
\hline Levene Statistic & df1 & df2 & p \\
\hline 22,294 & 4 & 351 &, 000 \\
\hline
\end{tabular}

Levene:22,294; $\mathrm{p}<0,05$ sonucunda varyansların heterojen bir dağılım gösterdiği tespit edilmiştir. Bu durumda tek yönlü varyans analizi (Anova) 
homojen olmayan post-hoc tekniği sonuçlarına bakılmıştır.

Tablo 7. Cinsiyete göre adaylarn eğitim durumuna ilişkin dağılım.

\begin{tabular}{|c|c|c|c|c|c|c|}
\hline \multirow{2}{*}{$\begin{array}{l}\text { Gruplar } \\
\text { (I) }\end{array}$} & \multirow{2}{*}{$\begin{array}{l}\text { Gruplar } \\
\text { (J) }\end{array}$} & \multirow{2}{*}{$\begin{array}{l}\text { Ortalamanın fark- } \\
\text { ları (I-J) }\end{array}$} & \multirow{2}{*}{\multicolumn{2}{|c|}{ Standart hata P }} & \multicolumn{2}{|c|}{ 95\% Güven aralığı } \\
\hline & & & & & Alt sinır & Üst sınur \\
\hline \multirow{4}{*}{1 saatten az } & 1-2 saat &,$- 66892^{*}$ & ,15360 & ,000 & $-1,1094$ &,- 2284 \\
\hline & 3-4 saat &,$- 90199^{*}$ & ,13474 & , 000 & $-1,2916$ &,- 5124 \\
\hline & 5-6 saat & $-1,06637$ & ,20174 & ,000 & $-1,6473$ &,- 4855 \\
\hline & 7 saat ve üzeri & $-2,31081^{*}$ & ,11520 & ,000 & $-2,6529$ & $-1,9687$ \\
\hline \multirow{4}{*}{$1-2$ saat } & 1 saatten az & $66892^{*}$ & ,15360 & ,000 & ,2284 & 1,1094 \\
\hline & 3-4 saat &,- 23307 & ,12332 & 460 &,- 5834 & 1173 \\
\hline & 5-6 saat &,- 39745 & , 19430 & ,355 &,- 9566 & , 1617 \\
\hline & 7 saat ve üzeri & $-1,64189^{*}$ & , 10160 &, 000 & $-1,9347$ & $-1,3491$ \\
\hline \multirow{4}{*}{$3-4$ saat } & 1 saatten az & ,90199* & , 13474 & , 000 &, 5124 & 1,2916 \\
\hline & $1-2$ saat & 23307 & ,12332 & 460 &,- 1173 &, 5834 \\
\hline & 5-6 saat &,- 16438 & ,17976 & 987 &,- 6856 & ,3568 \\
\hline & 7 saat ve üzeri & $-1,40882^{*}$ & ,06989 & ,000 & $-1,6070$ & $-1,2107$ \\
\hline \multirow{4}{*}{$5-6$ saat } & 1 saatten az & $1,06637^{+}$ & ,20174 & ,000 &, 4855 & 1,6473 \\
\hline & $1-2$ saat & ,39745 & , 19430 & ,355 &,- 1617 & ,9596 \\
\hline & 3-4 saat & 16438 & ,17976 & 987 &,- 3568 & ,6856 \\
\hline & 7 saat ve üzeri & $-1,24444^{*}$ & ,16562 & , 000 & $-1,7310$ &,- 7579 \\
\hline \multirow{4}{*}{7 saat ve üzeri } & 1 saatten az & $2,31081^{*}$ & ,11520 & , 000 & 1,9687 & 2,6529 \\
\hline & $1-2$ saat & $1,64189^{*}$ & , 10160 & , 000 & 1,3491 & 1,9347 \\
\hline & 3-4 saat & $1,40882^{*}$ & ,06989 & , 000 & 1,2107 & 1,6070 \\
\hline & 5-6 saat & $1,24444^{*}$ & ,16562 & , 000 & ,7579 & 1,7310 \\
\hline
\end{tabular}

Games-Howell tekniğinin kullanıldığı post-hoc analizi sonucunda ergen bireylerin gün içinde sosyal medya kullanımları ile aile içi iletişim süreçleri karşılaştırıldığında en yüksek ortalamanın 7 saat ve üzerinde sosyal medya kullanan grupta olduğu görülmektedir. En düşük ortalamanın ise gün içinde 1 saatten az sosyal medya kullanan grupta olduğu tespit edilmiştir.

Tablo 8. Ergen bireylerin cinsiyetleri ile aile içi paylaşımlarına ilişkin t-testine yönelik bulgular

\begin{tabular}{llllllll}
\hline Değişken & Cinsiyet & $\mathbf{N}$ & $\bar{X}$ & SS & SD & t & p \\
\hline Sosyal Medya & Erkek & 204 & 2,51 & 1,046 & \multirow{2}{*}{354} & $-1,759$ &, $079^{*}$ \\
Kullanım Süresi & Kadın & 152 & 2,70 &, 954 & & & \\
\hline
\end{tabular}

Tablo 8'de ergenlerin cinsiyetleri ile aile içi paylaşımları arasında anlamlı bir farklılığın olup olmadığına yönelik bulgulara yer verilmiştir. Yukardaki tabloda da anlaşılacağı gibi t -testi bulgularında ergen bireylerin cinsiyetlerinin aile içi paylaşımları ile arasında anlamlı bir farklılık olmadığını ortaya koymaktadır $(\mathrm{p}<0.05)$. 
Tablo 9. Ergen bireylerin cinsiyetleri ile aile içi paylaşımlarnna ilişkin t-testine yönelik bulgular

\begin{tabular}{lllllll}
\hline $\mathbf{R}$ & $\mathbf{R}^{\mathbf{2}}$ & $\mathbf{P}$ & $\mathbf{t}$ & $\mathbf{B}$ & $\mathbf{S D}$ & $\boldsymbol{\beta}$ \\
\hline, 472 &, 223 &, 000 & 10,080 &, 460 &, 046 &, 472 \\
\hline
\end{tabular}

Çalışmanın temel problemi olan ergen bireylerin aile içi iletişim süreçlerine katılım düzeyleri ile sosyal medya kullanımı arasında yapılan regresyon analizi sonuçlarına göre bir ilişki bulunmaktadır. T değerinden bu ilişkinin anlamlı bir ilişki olduğu kantlanmaktadır ( $p=0.00$ ). Ergen bireylerin sosyal medya kullanımı aile içi iletişimdeki katılım düzeylerinin yüzde 22 sini açıklamaktadır $\left(R^{2}\right.$ $=$,223). Yani aile içi iletişim süreçlerinde ergen bireylerin bu süreçlere katılıp katılmamasında sosyal medya yüzde 22 oranında belirleyici olmaktadır.

\section{Sonuç}

Sosyal medyanın toplumsal yapı içirişinde dönüştürücü bir uzam olduğu genel kabulü ile desenlenen bu çalışmada, sosyal medya kullanan ergen bireylerin aile içi iletişim süreçlerine katılım noktasında sosyal medya kullanımının anlamlı ilişkisi üzerine nicel bir analiz yapılmıştır. Çalışma, Z kuşağı olarak değerlendirilen 'ergenlerin fiziksel olarak katılım sağladığı aile içi iletişim süreçlerine katılım düzeyleri ile sosyal medya kullanımı arasında ilişki olup olmadığ 1 temel problemi üzerine kurgulanmıştır.

Çalışmanın merkezinde bulunan bu temel problem için basit doğrusal regresyon analizi yapılmıştır. Bağımlı değişken olarak Ümit Demir' in Sosyal Medya Kullanımı ve Aile İçi İletişim Ölçeği', bağımsız değişken olarak ise ergenlerin günlük sosyal medya kullanım süreleri veri analiz sürecine dahil edilmiştir. Analiz sonuçlarına göre sosyal medya kullanan ergen bireylerin aile içi iletişim süreçlerine katılım noktasında sosyal medya \% 22 oranında belirleyici olmaktadır. Yani ergen bireylerin aile içi iletişim süreçlerine katılım düzeylerindeki azalma sebepleri arasında sosyal medyanın \% 22'lik bir etkisi bulunmaktadır.

Çalışmada veri setine dahil edilen kullanıcıların hepsi sosyal medyayı aktif bir şekilde kullanmaktadır. Bu bağlamda sosyal medya, ergen bireyler için gün içinde katılım sağlanması gereken bir uzam haline dönüşmektedir. Hem fiziksel hem de dijital ortamlara gün içinde katılım sağlayan ergen bireylerin ilişkileri de bu uzamların aidiyetleri altında belirlenmektedir. Özellikle gün içinde sosyal medyayı kullanım süreleri arttıkça fiziksel katılım sağlanan organizasyonlardaki ilişki pratikleri azalmaktadır. 


\title{
EXTENDED ABSTRACT
}

\section{Social Transformation of Social Media: A Quantita-tive Research on the Participation Levels of Adoles-cents Using Social Media in Family Communication Processes}

\author{
Serpil Kur Elitaş \\ Hatay Mustafa Kemal University
}

The internet, which has a wide place in the life of modern people, has become one of the indispensable foundations of life with the spread and diversification of services today. With the solution of many businesses and transactions over the internet in a shorter time, the variety of services, communication tools and shopping, the internet has become the center of the lives of individuals. The close relationship between technology and the individual has led to a new interaction and communication environment. Individuals share their knowledge, thoughts and experiences with each other, and these shares change the relationships and behaviors of individuals with each other. Social media that developed during this period offers an easy way to communicate with your new and old friends, to follow networks, and to follow brands and companies. It has become an integral part of adolescents' daily lives and one of the most popular forms of communication used by the majority. On the other hand, "The more time spent on social media, the less family relationships decrease. Adolescents who spend most of their time on social networking become lonely and isolated individuals from social life in their rooms. Individuals who complete the communication gap with social media or add new practices to their communication arguments prefer to spend time on the Internet instead of doing social activities, and this reveals the situation of family members to spend their spare time separately. Young people who isolate themselves from social life become a part of the virtual world by moving away from real life events and may be deprived of socializing towards physical life. In addition to socialization problems, social media also has negative effects on adolescents' peer relationships. Social media negatively affects family communication, peer communication and parent-child communication. 
Based on this idea, the question of "whether there is a relationship between the levels of participation in social communication with adolescents and the use of social media" is the main problem of the study. In addition, the study sought answers to the following questions:

- Is there a significant difference between adolescents' genders and social media usage histories?

- Is there a significant difference between adolescents' usage of social media during the day and their family sharing?

- Is there a significant difference between adolescents' gender and family sharing?

The universe of the study consists of 2080 students living in the province of Hatay and studying in the 9th, 10th, 11th and 12th grades in four Science High Schools operating in the province. The sample unit that will represent the universe of the study was carried out with 356 participants, 204 of whom were male and 152 of which were female, of the users included in the data set. From this aspect, it was concluded that the study was appropriate in terms of both gender representation and the adequacy of the sample. Participants are adolescent individuals aged 14 to 18 years old. Participants were asked to fill the 32 -item questionnaire on a voluntary basis. The questionnaire form created to determine the social media usage information and the effect of this situation on family communication was created by using the 'Social Media Use and Family Communication Scale'. Within the scope of the study, the questionnaire form was applied to the students who continue their education in four secondary education institutions in Hatay province in the spring term of 2018-2019 academic year.

The research was carried out with 356 participants, 204 boys and 152 girls. From this aspect, it was concluded that the study was appropriate in terms of both gender representation and the adequacy of the sample. Participants are adolescent individuals aged 14 to 18 years old. Participants were asked to fill the 32-item questionnaire on a voluntary basis. In this study, which was produced based on the idea that social media has a transformative effect on social structure, a quantitative analysis was made on the relation between the participation of adolescent individuals using social media in family communication processes and the use of social media. The study is based on the basic problem of "Is there a relationship between the level of participation of adolescents physically involved in family communication processes and the use 
of social media". According to the analysis results, social media is determinant by $22 \%$ in the participation of adolescents who use social media in family communication processes. In other words, social media has a $22 \%$ impact among the reasons for the decrease in the level of participation of adolescents in family communication processes. Participants actively use social media. With this thought, social media turns into a factor that enables adolescents to maintain their lives throughout the day. Adolescent individuals develop their relationships around social media, and determine their participation in physical environments according to their activity in social media.

\section{Kaynakça / References}

Aslan, N. , Cansever, B. (2012). Ergenlerin boş zaman değerlendirme algısı. Hacettepe Üniversitesi Eğitim Fakültesi Dergisi, 42 (42), 23-35.

Baltacl, A. (2018). Nitel araştırmalarda örnekleme yöntemleri ve örnek hacmi sorunsalı üzerine kavramsal bir inceleme. Bitlis Eren Üniversitesi Sosyal Bilimler Enstitüsü Dergisi, 7(1), 231-274.

Demir, Ü. (2016). Sosyal medya kullanımı ve aile iletişimi: Çanakkale'de lise öğrencileri üzerine bir araştırma. Selçuk İletişim, 9 (2), 27-50.

Elitaş, T. (2015). Social media usage by open education faculties: Atatürk University case. Procedia-Social and Behavioral Sciences, 176, 243-250.

Güleç, V. (2018). Aile ilişkilerinin sosyal medyayla birlikte çöküşü. Yeni Medya Elektronik Dergisi, 2(2), 105-120.

Haciefendioğlu, Ş. (2014). Sosyal medyanın marka bağlllığına etkisi üzerine bir araştırma. Kocaeli Üniversitesi Sosyal Bilimler Dergisi, 28, 59-70.

Karan G. (2006). Anne babalar için internet rehberi. Epsilon Yayıncılık: İstanbul.

Kırık, A. M. (2014). Aile ve çocuk ilişkisinde internetin yeri nitel bir araştırma. Ĕ̆gitim ve Öğretim Araştırmaları Dergisi. 3(1), 337-47.

Tabachnick, B. G., Fidell, L. S. (2013). Using multivariate statistics (6th ed.). Pearson Publications: Boston.

Villegas, A. (2013) The influence of technology on family dynamics. Proceedings of The New York State Communication Association. 1-17.

We are social ve Hootsuit (2019), 'Dijital 2019 in Turkey [Online] 19.09.2019 tarihinde https://dijilopedi.com/2019-turkiye-internet-kullanim-ve-sosyal-medyaistatistikleri// adresinden erişilmiştir. 


\section{Kaynakça Bilgisi / Citation Information}

Kır Elitaş, S. (2020). Sosyal medyanın toplumsal dönüştürücülüğü: Sosyal medya kullanan ergenlerin aile içi iletişim süreçlerine katılım düzeyleri üzerine nicel bir araştırma. OPUS-Uluslararası Toplum Araştırmaları Dergisi, 16(30), 2616-2632. DOI: 10.26466/opus.777748 